\title{
SOME ASPECTS OF INTERNATIONAL OFFENCES: OFFENCES/CRIMES AND OFFENCES/DELICTS Denisa BARBU
}

\author{
"Valahia" University, Târgovişte, Romania \\ denisa.barbu77@yahoo.com
}

\begin{abstract}
Generally, justifying the theme aims to analyse the two categories of international crimes, i.e. offences/delicts and offences/crimes emphasizing the similarities and the differences between them because on the basis of the conclusions which will result and the degree of danger we can argue the framing of some of the offences/delicts under the category of offences/crimes, what we think it could help to reduce the criminality.

The element of novelty of the study is characterized by the fact that it is intended to be a review of all aspects of the efficiency of international co-operation in preventing and combating international crime/offences, on all levels, respectively, political, legal, technical and operative, in the framework of the most important mechanisms developed and agreed by states in this area.

Committing such severe acts, which violates any international regulation, requires states to fight back entirely, punishing the guilty ones. The legislation in force and the doctrine, the jurisprudence recognizes the principle according to which the offense is the only basis of criminal liability.

The notion of ,crime” in its sphere includes both offences committed with intent or negligence, and also the crimes of common or international law.
\end{abstract}

Keywords: infraction, tort, crime, responsibility, social danger

\section{Introduction}

The actuality is given by the fact that criminal liability in international law is one of the fundamental problems of contemporaneity, as well as the controversies of doctrine with respect to an individual, whether or not the subject of international law, and hence, whether or not is internationally liable [1].

On the other hand, the need for in-depth discussion, of rethinking, nuancing the sanctions system applied to a physical person is generated by multiplying the offences/crimes, with international involvement of senior officers in some States which tolerate, encourage or participate in such atrocities.

In the context of the intensification of actions that can be placed in the category of international crimes and offences (of terrorist offences, computer crime, economic offences, offences of corruption), the transnational cooperation to detect and punish those who are guilty is essential. Today, no State can fight alone with such phenomena.

In fact, justifying the theme aims at indepth analysis of those two categories of international crimes, i.e. offences / delicts and offences / crimes with demonstration of the similarities and differences between them on the basis of the findings of what will result and the degree of danger we can argue the employment of some of the offences/ delicts under the category of offences /crimes, what we think we could help reduce criminality. We believe that it is necessary to emphasize the implications of 
participation in national and international laws criminalizing offences and crimes, international obligations of cooperation with international bodies and with States, even more so, as Romania, in 2013, held the position of co-facilitator of the action plan for the universality and full implementation of the Rome Statute, and on 8 December 2014, Romania, was elected a member of the Bureau of the Assembly of States-parties to the Rome Statute. The supremacy of the international law, in general, in relation to domestic law, including criminal matters, calls for the integration of the "actual" imperative of the Rome Statute with related amendments in national legislation of the States parties [2], which entails the obligation of denunciation of the crimes and delicts. Taking into account the multitude of terrorist attacks and other dangerous acts, we consider that it would be appropriate to establish an alert system to prevent the Commission of dangerous facts.

Whereas such offences have adverse effects on the interests of the international community in its entirety, have been covered in the framework of the international conventions, with the obligation for States to criminalize and punish them on the basis of national legislation or by virtue of customary rules of international law.

Criminal liability is an attribute of man, of the individual and not of the authorities. Therefore, in the event of unlawful criminal acts committed by a State against other States, and claimed by the criminal proceedings, criminal liability is not the responsibility of the State, but his representatives, i.e. those who ordered or executed such an offence. It is generally accepted that individuals, acting as organs of the State, committing intentional crimes whenever they decide, ordered or carried out acts of indictment and punishment which them are provided for in international law, in this case, along with the international responsibility of the State, where appropriate, Act and the penal responsibility of the persons concerned.

According to the Dictionary of public international law, the international offence constitutes the offence contrary to the principles and rules of public international law committed by States (central or local bodies), international organizations or private individuals and which attracts international liability of the culprit.[3]

A more elaborate definition of international crime is that international crime is an act consisting of an action or omission, contrary to international law, of which essential element is the manifest for dangerousness for the international peace and security and other supreme values of humanity, which attract the criminal sanction.[4]

In another definition, V. V. Pella, one of the forerunners and founders of the criminal international law, shows that international crime is the action or omission punished with a sentence pronounced and executed on behalf of the States. [5] Beyond the differences between these definitions (and others), there are clearly shown the constitutive elements of crime of international economic backgrounds and [6]: the material element, such as physical and material act voluntarily committed only by individuals (because only individuals are liable even when the author is the State) or in the form of an action (delicta comissiva), either in the form of omission (delicta omissiva); the illegal item, as a fundamental element expressed in that action (inaction) is contrary to public international law; a subjective element, which expresses the ratio between the author and the causative act, i.e. both the will to Act (willing) and consciousness (intellective) of the illegal character of the deed [2, p. 18-19; 7].

Within the above definitions [8] an essential aspect with respect to international crimes is not specified, namely, the appearance of incrimination of such acts by virtue of the principle of legality [9].

A deed, to be prosecuted as a criminal offence, must be internationally qualified as 
such on the conventional path, because the lack of incrimination of the crime through international treaties makes it nearly impossible to punish the perpetrators, this being one of the causes that led to the exponential growth of breaches in the public international law [10].

Another drawback of the definitions set forth is that the definition should reflect the dual aspect of the international crime, according to the dangerousness of the values protected by it. Thus, some international crimes are crimes with a high degree of dangerousness, because they oppose fundamental values and essential for the international community, as well as international peace and security, the sovereignty of States, the existence of human groups, etc. [11]. In turn, other crimes are qualified as delicts or simple offences, presenting a lower risk than the international crimes.

The international crimes are particularly serious and affect the international peace and security (genocide, crimes against humanity, war crimes, and the crime of aggression), and delicts represent forms of international offences which are less serious for the States that due to this reason were not included in the category of crimes (piracy, illicit trafficking in persons, illicit trafficking in narcotic drugs, torture, offences against the environment, computer crimes the offences of corruption, etc.) [12].

\section{Elements of similarity}

Some of the specific principles of the criminal process are: the principle of the criminal law; the application of the criminal law of de-penalizing, (criminal law does not apply to international offences committed under the old law, mightierlaw enforcement, which always lead to extraactivity of the criminal law), the principle of territoriality, the principle of mutual recognition of judgments, the principle of universality, the reality principle of the criminal law, the principle of the immunity from judicial proceedings, etc.

Another similarity is that they are indirect sources of criminal law treaties and international conventions (in this respect, we must note: the Convention against torture and other punishments or cruel, inhuman or degrading treatment (1984), the 1971 Convention for the Suppression of unlawful acts against the safety of civil aviation, the criminal Convention on corruption (1999), and the framework decisions of the Council of the EU aimed at harmonising the laws of the Members States (for example the framework decision no. 2002/584/JAI of 13 June 2002 on the European arrest warrant and the procedures for the submission between Member States).

As regards the way of instituting, the similarities are is made by any person aggrieved/ by a State party to the Rome Statute, by any person who has knowledge of the Commission of the offence or by the Prosecutor or UN Security included referral to the Office of the Prosecutor. In relation to the referral, it should be noted that the Prosecutor's freedom is assured of starting or not the investigations in all aspects and on all persons, unless there is reasonable suspicion of the existence of the offence/crime [1, p221-232].

With regard to the competence ratione temporis, the criminal law does not retroactivate, only sanctioning offences/crimes covered by the law in force, and with regard to the competence ratione locii, the first criterion which will attract the jurisdiction will be that of the territory where the Act was committed, as in the case of the jurisdiction ratione personae the penal responsibility is an attribute of an individual, and not of a (State) authority.If set, otherwise, this would lead to the exoneration ipso factoof the real authors of international offences/crimes, leading to similarities in all three cases.

Other similarities are found in the constitutive elements of the international offence/ crime, thus, these are:

a) The material element consisting of a physical act, volunteer, which manifests itself in two forms: as action (delicta 
commissiva) or inaction or omission (delicta ommissiva) [13].

b) The illicit element - illegality which makes the existence of the offence, which attracts the penalty,illegality resulting from the violation of a rule of international law contained in a Convention, custom, or from a contrary act to international justice and equity.

International offences / crimes cannot be repressed if certain causes that remove awareness of violations of international humanitarian law have occurred (the consent of the victim, the force majeure, the state of necessity, the self-defence, and the countermeasures) or whether these acts were committed within the limits of the obligations arising from international treaties.

c) The moral element: to be in the presence of an international offence / crime, the suspect fact must be attributable to the author. It puts into question the form of guilt, which encompasses both the will to commit the deed, as well as the international awareness of the illicit deed [7, p. 110]. The phenomenon of globalization, which marks the twenty-first century, has a direct impact on crime, which had new transnational values in the recent years.

\section{Distinctions}

Moving to the second part of our study, we must note that this refers to the differences between offences and crimes which are found in the applicable law. Thus, the Court applies the provisions of the State, of the Geneva Conventions on international humanitarian law, as well as other international conventions and custom, in prosecuting the cases within its competence.

Due to the criminal nature of the crimes, they are also applicable and the General principles of criminal law (legality of criminalization and punishment, criminal law penalties, individual criminal responsibility), and in the event of offences the national criminallaw shall apply, in accordance with the principle of territoriality.

In addition to international crimes falling under the jurisdiction of the International Criminal Court, the international community has prohibited and punished separately through international conventions and other actions endangering social at international level such as: international terrorism, piracy, theft of nuclear materials, slavery, illegal use of weapons, biological experiences, drug production and trafficking, illegal use of the postmark, the acts of serious environmental damage (committed in other circumstances than those specific to crimes against humanity, war crimes or genocide), currency counterfeit offences, corruption, etc. Corruption is one of the most serious threats to the rule of State law within contemporary society, undermining democratic institutions and values. Furthermore, there is a connection between corruption and other forms of crime [14];this is developing a transnational character [15]. In these circumstances the first reactions came from the society, which has forced Governments to take a series of measures to prevent and combat this phenomenon.

Global movement against corruption has come in three distinct phases, starting in the late 1990s, when anti-corruption strategies and specialized anti-corruption bodies appeared with duties and powers allowed, at least theoretically, acting effectively to combat corruption. The second phase consisted in the preparation and development of international anticorruption policies and mechanisms, global and regional dimensions, which were entered on line to achieve the following objectives: promoting political commitments, developing and implementing common policies, standards, criteria and standards for the legal classification of the Department of corruption, streamlining the operational cooperation for combating corruption; stepping up the exchange of experience, 
monitoring the evolution of the phenomenon of corruption and the implementation by States of the measures outlined above.

This is the era of multinational conventions and programs promoted through international organizations, culminating in the signing of the United Nations Convention against corruption in Mexico in December 2003. From this point on the fight against corruption is in a third phase, far more difficult and far away perhaps the most challenging of them, which is the implementation and application of international standards established by these international mechanisms.

\section{Conclusions}

Because the responsibility of the individual to be effective, it must operate at high working parameters with international criminal tribunals States. At the same time, the international cooperation in criminal matters is not a cooperation which runs horizontally, only between sovereign States, but also vertically, between States and the international criminal tribunals, thus we can speak of creation, based on international cooperation in criminal matters, a transnational criminal justice.

Whereas the effectiveness of sanctions (punishment) is biased and the speed with which they are established and applied in practice, we believe that it would be necessary that international instruments contain explicit provisions in this respect. We also point out that it would require a more thorough regulation of arrangements for cooperation of States. We even mention that the acts of terrorism with particularly serious consequences or that present a danger raised by the way of committing, should be included in the category of international crimes within the competence of the International Criminal Court.

\section{References}

[1] Denisa Barbu, Răspunderea persoanei fizice în dreptul internaţional penal, ed. Lumen, Iasi, pp.17-18,2015.

[2] Denisa Barbu, Genocidul, infracţiunile contra umanităţii şi cele de război. Repere în Codul penal roman în raport cu statutul de la Roma, Ed. Lumen, Iaşi, pp.77-78, 2015.

[3] Dicţionar de dreptinternaţional public, Editura Ştiinţifică şi Enciclopedică, Bucureşti, p. 74,1982.

[4] Grigore Geamănu, „Dreptul internaţional contemporan”, Editura Didactică şi Pedagogică, București, p. 546,1975.

[5] V.V. Pella La criminalitte collective des Etats, București, p. 185,1926.

[6] M.I. Niciu Dreptinternaţional public, Editura Servosat, Arad, p. 132, 1999.

[7] Claude Lambois, Droit penal international, Dalloz, Paris, p.37, 1974.

[8] St. Gloser, Infraction internationale, Dalloz, Paris, p.110, 1971.

[9] Dumitra Popescu, Felicia Maxim, Dreptinternaţional public, Ed. Renaissance, Bucureşti, p.322, 2011.

[10] Nguyen QuocDinh şi alţii, Droit international public, 8eme edition L.G.D.J., Paris, p.788, 2009.

[11] David Ruzié,Droit International Public, 15eme edition, Edition Dalloz, Paris, pp.264266, 2000.

[12] Stelian Scăunaş, Răspunderea internaţională pentru violarea dreptului internaţional, Ed. All Beck, Bucureşti, p.83, 2002.

[13] Costică Voicu, Florian Coman, Ştefania-GeorgetaUngureanu, Drept internaţional penal, Editura Pro Universitaria, p. 144,2007.

[14] George T. Abed, Sanjeev Gupta, Governance, Corruption and Economic Performance, International Monetary Fund, WashingtonD.C., p.58-59,2003.

[15] http://eur.europa.eu/. 